\title{
GUATEMALAN IXIL COMMUNITY TEACHER PERSPECTIVES OF LANGUAGE REVITALIZATION AND MOTHER TONGUE-BASED INTERCULTURAL BILINGUAL EDUCATION
}

\author{
Kelly Dalton ${ }^{1}$ \\ Marymount University, USA \\ Sarah Hinshaw \\ George Mason University, USA \\ John Knipe \\ Limestone College, USA
}

\begin{abstract}
Recent scholarship indicates several benefits of mother tongue education (MTE) in supporting student learning. Within one Mayan community in Guatemala, Ixil is the mother tongue spoken at home and faces extinction due to Indigenous oppression and genocide. This qualitative case study highlights efforts of 13 teachers and administrators at one primary school that took up the dual task of offering MTE and revitalizing the Ixil language. In order to gain a better understanding of Indigenous teachers' perceptions of language, culture, and MTE, this research was guided by the following questions: (1) How do teachers perceive their own understanding of attitudes and beliefs about language and culture? (2) How do they perceive their role in MTE and language revitalization? (3) Are teachers critical in their understanding of the importance of language revitalization and best practices for language pedagogy? Data was collected via site observations and surveys, then analyzed using constant comparative analysis. Themes that emerged included how teachers perceive their language revitalization and MTE agentive roles; how agency is expressed through the process of negotiating language and understanding through literacy; and addressing local priorities. Implications of the study and for future study are discussed.
\end{abstract}

Keywords: Minority Group Teachers, Teacher Attitudes, Language Revitalization, Bilingual Intercultural Education, Intercultural Competence

${ }^{1}$ Correspondence: Rowley Hall, 1004D, Marymount University, 2807 N. Glebe Rd. Arlington, VA 22207; kellymcdalton@gmail.com 


\section{Introduction}

In Guatemala, the population is $39.5 \%$ Indigenous (mostly of Mayan descent), $41 \%$ Ladino (of mixed Amerindian-Spanish descent), and 18.5\% of European descent (Instituto Nacional de Estadística, 2010). Over half the country lives below the national poverty line, and those that do are typically Indigenous groups and rural populations. The country continues to struggle in the areas of health, development, and literacy, with almost half of all children under the age of five suffering from malnutrition (United Nations International Children's Emergency Fund, 2019). The Mayan, or Indigenous, groups continue to be disproportionately affected by poverty, malnutrition, and lack of access to mother tongue education.

There are currently 23 Indigenous languages spoken throughout Guatemala. Apart from Garífuna, an Arawakan language, all of these languages are in the Mayan language family. These language groups are spread predominantly throughout the central area of Guatemala. While most of these languages are abstand in relationship to one another (i.e., they are discrete and not mutually intelligible), some are considered ausbau in relationship (i.e., some mutual intelligibility though separate languages), and still some, such as Kaqchikel-K’iche', are even considered mixed languages.

A variety of language policies that supported or outlawed Mayan language use and mother tongue education in classrooms have gone through cycles of being implemented, overturned, and abolished. Mother tongue education refers to the use of a child's first language as the medium of instruction, and has been identified as an important component of quality education (UNESCO, 2003). Throughout the country's 36-year civil war, Indigenous social movements began to take place and the current practices and policies that supported mother tongue-based education were debated (Herdoiza-Estevez \& Lenk, 2010; MedinaLopez-Portillo \& Sinnigen, 2009). Intercultural bilingual education (IBE) and the concept of la interculturalidad, or interculturality, were introduced to transform and replace dominant notions of Mother tongue-based bilingual education into a more inclusive discourse with the aim of establishing equity for ethnic minority groups, while equally valuing both majority and minority languages (Herdoiza-Estevez \& Lenk, 2010).

In post-conflict Guatemala, Mayan language rights have been improving, but the work of language revitalization continues to be a long and arduous process. Negative attitudes toward languages not connected to status and power continue to promote monolingual norms (Herrera \& Wedin, 2010). These language attitudes are particularly impactful in Guatemala where a large portion of the population does not speak Spanish as their first language, and therefore, children are "taught through a language that they fail to master at primary school, a language that in many cases, not even the teachers themselves master" (Herrera \& Wedin, p. 236). School enrollment, funding, and bilingual education continues to grow in Guatemala, but issues persist with dropout rates, grade repetition, and lack of literacy materials in indigenous Mayan languages (Marques \& Bannon, 2003). Furthermore, even when IBE is supported by educational policies, status is still connected to the majority language and the motivation of schools that serve minority communities is usually directed toward developing Spanish language skills (Herrera \& Wedin, 2010).

The aim of this paper is to use a case study of teachers' perspectives as practitioners of Mother tongue-based education and IBE to better understand the critical role they play. We hypothesize that the teachers' attitudes and experiences of language and culture would reflect the current literature focused on IBE in other Latin American countries. This paper has been laid out in the following way to show our process. First, we will review the literature 
on policies that historically shaped Indigenous Mother tongue-based bilingual, interculturality, and IBE movements within Latin America, and applications for teaching pedagogy (relating to Intercultural Competence [IC], interculturality, and language revitalization). Second, we present the methods and findings of a case study of how Ixil Mayan teachers at one additive bilingual school perceived their understandings of language, culture, and interculturality. Third, we reflect on our emerging understandings of educators' roles in Mother tongue-based bilingual and IBE within international research settings and discuss implications for future research.

\section{Mayan Bilingual Education}

The Indigenous Mayan civilization flourished in this region of the world until the Spanish colonization of Guatemala in the early 1500s (CIA, 2014; Helmberger, 2006). Through the process of castellanización, a hegemonic ideal that forced the Indigenous peoples to abandon their ways of life, Mayans were taught Spanish for the purposes of converting them to Christianity and for turning them into productive workers (Helmberger, 2006; Richards \& Richards, 1997), which resulted in centuries of exploitation, oppression, and racism (Arias, 2006). After Guatemala won their independence in 1821, the Ladino government set policies and actions in place to maintain castellanización by establishing a nation state unified by one culture and one language (Bitar, Pimentel, \& Juarez, 2008; Helmberger, 2006). The Indigenous peoples were blamed for the difficulties the country faced in creating this unified culture and language. Therefore, the Spanish language was used as a tool to assimilate and oppress Mayans and policies were established that prohibited accommodation or allowance for Mayan languages (Bitar et al., 2008; Helmberger, 2006).

In the 1940s, the Instituto Indigenista Nacional (IIN) was created to further deal with the "Indian" problem and enforced assimilation projects that supported Spanish as the language of power and prestige (Bitar et al., 2008; Helmberger, 2006). Mother tongue education policies were instituted as a means for Mayans to replace their native languages by gaining fluency in Spanish. Teachers working with Indigenous students taught literacy in the home language before Spanish (Helmberger, 2006). Furthermore, IIN created a Roman character, Mayan language alphabet that was not inclusive of Mayan dialects but instead favored Spanish sounds and spelling patterns (Helmberger, 2006; Richards \& Richards, 1997). Mayan languages that could not be easily translated into Spanish, including Ixil, were left unwritten (Helmberger, 2006; Richards \& Richards, 1997). In the 1960s, programs like the Bilingual Castellanización Program and National Bilingual Education Project were designed to further facilitate the transition from mother tongue to Spanish (Helmberger, 2006). Both worked with a monolingual language ideology that allowed the use of Mayan languages in pre-primary and primary education with the goal of transitioning Indigenous populations to Spanish monolingualism. Also during this time, guerilla and military forces began a violent civil war, and "a simultaneous reign of terror on the part of the Guatemalan military aimed its animosity at civilians” (Helmberger, 2006, p. 72). This ideology of contempt mainly targeted the Mayan population.

Civil war. During the country's 36-year civil war, Guatemalans were faced with a series of dictatorships, insurgencies, coups and military rule and innocent Indigenous communities were specifically targeted (CIA, 2014; United States Institute of Peace, 1997). In the early 1980s, military dictator Rios Montt targeted the Ixil Triangle with his scorched earth campaign (Guatemala Human Rights Commission, 2011). It has been estimated that $70-90 \%$ of the Ixil villages were destroyed, which left 200,000 people dead (United States Institute of Peace, 1997) and countless more with immeasurable psychological 
trauma (Arias, 2006), not to mention interrupted schooling and thousands more missing. Horrific accounts of mass murders, torture, rape, and children being burned alive were shared by Mayans during the historical trial of former dictator Rios Montt, the first leader in world history to be tried of the atrocities committed under his reign (GHRC, 2011). With the signing of the Peace Accords in 1996, a commitment to human rights and preservation of a multicultural and multilingual Guatemala was established and bilingual education was instituted for the entire Mayan population (Helmberger, 2006; HerdoizaEstevez \& Lenk, 2010). This commitment theoretically gave equal weight to both Indigenous and Spanish languages, but bilingual education has been exclusively directed at Indigenous students (Herdoiza-Estevez \& Lenk, 2010). This implementation calls into question the integrity of such policies, as Herdoiza-Estevez and Lenk questioned, "is there a real effort from mainstream society to build bridges toward Indigenous peoples, or is this a unilateral project, meant exclusively to bring Indigenous peoples toward the mainstream?” (p. 206). No current policy requires Spanish-speaking Guatemalans to work toward mastery of any of the Indigenous languages, further bolstering the monolingual orientation toward a Spanish-speaking society.

\section{Interculturality and Intercultural Bilingual Education}

Intercultural bilingual education and the concept of interculturality were introduced in Latin America in the 1970's as an alternative to Mother tongue-based bilingual policies that perpetuated and ignored asymmetrical relations of power and prestige between Indigenous and Spanish languages (Tubino, 2013). Interculturality, as defined by MedinaLopez-Portillo and Sinnigen (2009), "points to the radical restructuring of the historically pronounced uneven relations of wealth and power that have existed between Europeans and their descendants and Indigenous and other subordinated groups during the last half millennium" (p. 25). Interculturality aims at both strengthening Indigenous ethnic cultural identity while questioning relations between majority and minority, Indigenous cultures (Tubino, 2013). Intercultural bilingual education, therefore, can be viewed as the application of interculturality within the educational system.

Language rights. Language, identity, and power are inextricably linked (Hornberger, 1998; Paulston, 1997). Within the Indigenous movements, "the preservation of an ethnic language is essential to the protection of cultural identity, self-esteem, self-respect, and traditional knowledge" (Herdoiza-Estevez \& Lenk, 2010, p. 203). Skutnabb-Kangas (2000) adds that many minority languages are proverbially dying at the hands of dominant languages (e.g., Spanish). Language rights for the Indigenous peoples in Guatemala have been an important component of the fight to prevent language loss. Formal education, according to Herdoiza-Estevez and Lenk, "may be the most critical area where the debate and praxis of language rights materializes" (p. 199).

In Guatemala, a national linguistic policy was established in 2002 that supported obligatory teaching and practice of interculturalism, as well as bilingualism for students in all recognized languages; the first language of instruction to be in a child's mother tongue, and the second in another national language (Internacional de la Educación, 2011). However, there is a disconnect between policy and practice throughout Latin America; "in spite of what constitutions, education laws and other relevant laws have provided, official IBE has been inadequately developed and relatively marginal in all the countries" (p. 21).

It is unclear how Indigenous teachers, within a formal educational system, conceptualize and act upon their understandings of interculturality and IBE. 


\section{Intercultural Competence Theory}

Interculturality "implies the sharing of experiences and physical and imaginary spaces among peoples who are culturally different" (Medina-Lopez-Portillo \& Sinnigen, 2009, p. 258). By looking to the field of intercultural competence theory and research, notions of culture and personal intercultural attributes can add to a deeper understanding of how crosscultural interactions take place within the "physical and imaginary spaces" of Indigenous teachers working in a Ladino dominated culture.

Objective/subjective culture. Interculturalists commonly use the constructivist definition of culture established by Berger \& Luckmann (1966) that differentiates between objective and subjective culture (Bennett \& Bennett, 2004); "objective culture is internalized through socialization and subjective culture is externalized through role behavior" (p. 150). Objective culture can refer to institutional aspects of culture such as political systems, and in education, generally refers to products of culture such as history, art, cuisine, literature, and music (Bennett \& Bennett, 2004). Subjective culture, on the other hand, "refers to the experience of the social reality formed by a society's institutions - in other words, the worldview of a society's people (p. 150). Understanding the local realities and contextualized experiences of Indigenous teachers can help inform current practices of IBE (Valdiviezo, 2010).

Intercultural competence components. Intercultural competence (IC) can be defined as "the ability to communicate effectively in cross-cultural situations and to relate appropriately in a variety of cultural contexts" (Bennett \& Bennett, 2004, p. 149). More specifically, IC is "the appropriate and effective management of interaction between people who, to some degree or another, represent different or divergent affective, cognitive, and behavioral orientations to the world" (Spitzberg \& Changnon, 2009, p. 7). These definitions, which can arguably be representative of "Western" understandings of IC, imply that individuals with divergent orientations to the world have equitable access to opportunities for the development and application of intercultural skills. These skills, specifically relating to communication, are wrapped up in language and which language is valued. For Indigenous populations, however, the ability to communicate has been controlled by those in power, resulting in centuries of linguistic and cultural oppression and genocide.

Hamilton, Richardson, and Shuford's (1998) model of intercultural competence components describes the attitudes, knowledge, and skills associated with interculturally competent interactants (Spitzberg \& Changnon, 2009). Within this model, attitude competencies included an appreciation for risk taking, awareness of the basic equality of groups, and appreciation for the role of cross-cultural interactions on quality of life. Knowledge competencies included understanding histories of oppression and cultural identities. Lastly, skill competencies included engaging in self-reflection, ability to take multiple perspectives, and challenging discriminatory acts (Hamilton et al., 1998; Spitzberg \& Changnon, 2009). It is important to consider how objective and subjective cultures shape intercultural competencies, particularly within an IBE framework, when oppression and marginalization have restricted the rights of one cultural group in favor of another.

The theories of Intercultural Communication began in the 1950 s with the anthropological work of Edward T. Hall through the Foreign Service Institute of the U.S. Department of State (Rogers, Hart, \& Miike, 2002) and were continually developed into the theories of Intercultural Competence over the following decades. There are multiple theories and assessment tools, each developed for specific disciplines (such as business, medicine, and education). There is no one agreed upon theory or assessment of IC and the field is still refining. The most prominent scholars in Intercultural Competence for the field of education 
are Blight (2012) and Tangen, Mercer, Spooner-Lance, and Hepple (2011). These researchers work on issues of how educators can teach students to be more Interculturally competent and not on the IC abilities of the educators. Therefore, this paper used the work of Spitzberg and Changnon (2009), Hamilton, Richardson, and Shuford (1998), Medina-Lopez-Portillo and Sinnigen (2009), and Bennett and Bennett, (2004) to build understanding of teacher IC and IBE.

\section{Intercultural Understanding}

The right to quality education for all Mayans is an important step to developing intercultural understanding in post-conflict Guatemala between Ladinos and Mayan ethnic groups because "bilingualism and multilingualism foster solidarity, social cohesion, and peace within multilingual settings" (Alidou, Glanz, \& Nikiema, 2011). However, as with many, if not all colonized nations and those ravaged by war, the lingering effects of oppression and violence pose many obstacles for fostering peace and understanding in a multicultural, multilingual Guatemala. It is important to recognize the history of Indigenous communities in order to develop an understanding of how these lingering effects are promoted, implicitly and explicitly, through attitudes around language, ethnicity, and cultural identity. In communities with large Indigenous populations, such as the Ixil Triangle in Guatemala, intercultural issues continue to be matters of extreme urgency (Medina-Lopez-Portillo \& Sinnigen, 2009).

Additive bilingual schools, such as the primary school at the center of our case study, are an important vehicle for students to connect to their mother tongue language, history, and culture and are examples of educational practices created as a response to language loss (Yazzie-Mintz, 2011). Yet the lack of research focused on Indigenous teacher perspectives of language, culture, and interculturality in this setting is surprising, given that the teachers are the main model of language use (Veilleux \& Bournot-Trites, 2005). It is especially important to understand the perspectives of Ixil Mayan teachers and how they bring about both academic achievement and Indigenous cultural and linguistic revitalization, particularly in the context of globalization and how economic, cultural, and political forces threaten minority linguistic, cultural, and educational rights (McCarty, 2003).

\section{Methodology}

In order to gain a better understanding of Indigenous teachers' perspectives of language, culture, and interculturality, this qualitative case study was guided by the following research questions: (1) How do teachers perceive their own understanding of attitudes and beliefs about language and culture? (2) How do they perceive their role in MTE and language revitalization? (3) Are teachers critical in their understanding of the importance of language revitalization and best practices for language pedagogy?

Conceptual Paradigm. Our inquiry stance is rooted in constructivist epistemology and a social justice framework (Patton, 2002). This perspective emphasizes the socially constructed nature of reality, is highly sensitive to the individual lived experience, and questions the consequences of individuals' constructions of reality for their behavior and for those with whom they interact (Maxwell, 2013; Patton, 2002). As the participants in this study are from an underrepresented minority group, and Indigenous narratives are not often represented by the literature, we believed it necessary to highlight their emic experiences. Due to the joint nature of this research project, heuristic inquiry is also implied in the data collection and analyses as the co-researchers intensively experienced and reflected upon the phenomenon in question (Patton, 2002). Rather than exacting precision and 
measurement, heuristic inquiry seeks to understand the lived experiences of participants. This iterative process is subjective in nature and requires exploration, reflection, and evaluation (Douglass \& Moustakas, 1985).

Case study. Case study methodology is particularly well-suited to explore this phenomenon, because it is a "preferred strategy when 'how' or 'why' questions are being posed, when the investigator has little control over events, and when the focus is on a contemporary phenomenon within real-life context” (Yin, 1994, p. 1). Furthermore, case study research is distinguished by "the study of an issue explored through one or more cases within a bounded system (i.e., a setting, a context)" (Creswell, 2007, p. 73). The case, or bounded system, for this study is the group of Indigenous teachers engaged in bilingual, mother tongue education at the Diego Edwards School. The single-case study presented here took place in naturalistic settings and drew upon multiple perspectives to produce an in-depth understanding of this bounded system.

Interculturality. In J. H. Sinnegen's introduction to Intercultural Practices in Latin American Nation States, the author provides a thick description of the conceptualization of la interculturalidad (interculturality) by Fidel Tubino, a leading scholar in the theory and praxis of la interculturalidad in Latin America (Tubino, 2013). Interculturality is "transformative action that goes beyond respect and tolerance and toward a dialogue intended to achieve cultural, economic and political equality with cultural diversity" (Tubino, 2013, p. 606). The goal is to turn "cultural diglossia," where Ladino cultures are considered more prestigious and desirable than Indigenous cultures, into an egalitarian democracy (Tubino, 2013). The Latin American conceptualization of interculturality and IBE serve as the guiding lens for data collection, analysis, and interpretation.

\section{Research Setting}

Ixil is an Indigenous language spoken only by an estimated 70,000 people who live in the Ixil Triangle, a remote geographic location in the Western Highlands of Guatemala (Lewis, Simons, \& Fennig, 2014). Ixil is one of the few Mayan languages that only existed in oral form until approximately ten years ago when groups of non-governmental organization (NGO) workers, teachers, and local community members began devising a writing system for the language. During this time, the Diego Edwards School was established by an NGO in the small farming village of Santa Avelina as an alternative to the local public school that used Spanish as the medium of instruction. Unlike subtractive bilingual programs that work toward supplanting one language with another, resulting in monolingualism, additive bilingual programs involve the teaching of content in two or more languages. The goal in additive bilingual education is fluency in one's mother tongue and an additional language or languages. The Diego Edwards School is the only additive bilingual program in the Ixil Triangle region where all teachers, administrators, and staff self-identify as Ixil - both culturally and linguistically, and fluent in Spanish. The school utilizes a 90/10 model of additive bilingual model of education, beginning mother tongue education in kindergarten then gradually shifting to dual language instruction in Ixil and Spanish, $10 \%$ and $90 \%$ respectively, by $6^{\text {th }}$ grade.

We believe this is an ideal location to study Indigenous teachers' perspectives of language, culture, and interculturality in post-conflict Guatemala. This setting represents an intersection of historical, political, cultural, social, economic, and linguistic contexts that create an environment where bilingual education is now implemented, but little is known about how these teachers perceive their language and culture and role in language revitalization within the current Ladino, Spanish language dominant system. 
Research relationships. The researchers gained access to the school through an international NGO, which founded the Diego Edwards School and an important gatekeeper to the Ixil community. We visited the school for two weeks as participant/researchers and lived fully immersed in community. During our two weeks, we assisted with the NGO's teacher professional development workshops, alongside U.S. volunteers, while also collecting data for the specific study. The researchers were three U.S. trained educators with varied experience domestically and internationally, but with traditional backgrounds from the global North. The backgrounds and belief structures of the researchers were based in the ideas of critical theory, wanting to gain understanding through collection of local Ixil teacher perspective in order to analyze how the teachers were cognitively connecting language revitalization, MTE, interculturality, and teaching practice.

\section{Participant Selection}

The unit of analysis for this case study was the group of 13 teachers and administrators at the Diego Edwards School. All teachers share a common culture and language - Mayan Ixil - and have lived within the geographical location of the Ixil Triangle

for most, if not all, of their lives. Yet within this small sample is a heterogeneous group of individuals with unique experiences. Using purposeful selection, we focused on four information-rich cases selected through purposeful, maximum variation sampling techniques (Reybold, Lammert, \& Stribling, 2013). To maximize the variation in this small sample, we identified criteria based on a variety of sources, including knowledge we obtained from being immersed in the research setting as a participant/researcher, relationships with the teachers, reflections with co-researchers, and impressions and statements of others, such as school administrators, and U.S. volunteers. The criteria included nature of work (grade and subjects taught), years teaching, age, gender, and percentage of estimated time speaking Spanish and Ixil in the classroom.

As shown in Table 1, this resulted in the purposeful selection of two female and two male participants. Pseudonyms have been provided to protect confidentiality. All participants self-identify as Ixil Mayan, speak Ixil as their mother tongue language, and are fluent in Spanish. Ximena is a young, estimulación temprano (early childhood) teacher who has been in the profession for two years. She mainly speaks Ixil with the children and introduces Spanish words in the classroom. Jairo is an older $5^{\text {th }}$ grade teacher who vividly remembers the civil war and comes from an influential family. Although he occasionally speaks Ixil in the classroom, he spends the majority of classroom time speaking in Spanish. María has been the principal for six years and had no teaching experience prior to this position. Carlos teaches physical education from pre-school to $6^{\text {th }}$ grade. Both María and Carlos frequently interact with children across the grades, and therefore speak Spanish and Ixil regularly throughout the day. We expected that any common patterns that emerged across these four, information-rich cases were of particular value in "capturing the core experiences and central, shared dimensions of the phenomenon” (Patton, 2002, p. 235).

\section{Data Collection}

Data collection consisted primarily of in-depth, semi-structured and informal interviews; supplemented by observations conducted by the researchers who served the roles of participant/researcher. All interviews and observations took place on-site and were conducted in Spanish. Four translators were available on-site, 24/7, to assist in translating conversations and interviews. The translators were Guatemalan translators from Guatemala City between the ages of $21-26$, two were male and two were female. They had never been to 
the school before and most had not spent much time with Indigenous Mayan people. They were told that the research was to better understand the dual language instruction for Ixil and Spanish within the school. Over the first day the researchers and translators discussed the need for direct translation of teacher response from Spanish to English in addition to the focus of the research to pull out the views of the teachers specifically.

Table 1

Profile of Interview Participants

\begin{tabular}{|c|c|c|c|c|c|}
\hline Name & $\begin{array}{l}\text { Age } \\
\text { Category }\end{array}$ & Gender & $\begin{array}{l}\text { Years of } \\
\text { Teaching } \\
\text { Experience }\end{array}$ & Job Title & $\begin{array}{l}\text { Language }(\mathrm{s}) \text { spoken } \\
\text { in school }\end{array}$ \\
\hline Ximena & $20-30$ & Female & 2 & $\begin{array}{l}\text { Early } \\
\text { childhood } \\
\text { teacher }\end{array}$ & $\begin{array}{l}\text { Mostly Ixil; } \\
\text { introduce some } \\
\text { Spanish words }\end{array}$ \\
\hline Jairo & $40-50$ & Male & 4 & $\begin{array}{l}5^{\text {th }} \text { grade } \\
\text { teacher }\end{array}$ & Mostly Spanish \\
\hline María & $30-40$ & Female & $6^{*}$ & Principal & $\begin{array}{l}\text { Mixture of } \\
\text { Spanish/Ixil }\end{array}$ \\
\hline Carlos & $20-30$ & Male & 5 & P.E. teacher & $\begin{array}{l}\text { Mixture of } \\
\text { Spanish/Ixil }\end{array}$ \\
\hline
\end{tabular}

Note. P.E. = Physical Education

* Principal for 6 years but no experience teaching in the classroom

Site observations. Observations of the community and classrooms included teacherstudent interaction, teacher-to-teacher interaction, and teacher-to-administrator interaction, particularly within the framework of interculturality and IBE and how it is being implemented throughout these various levels. The focus of teacher/student interactions was only on the teachers and no identifiable information was collected about the students. The community level observations included looking for the levels of presence of Ixil and Spanish in everyday conversation and the focus was on the presence of each language within the community.

Cross-cultural interviews. One-on-one, semi-structured and informal interviews took place on-site with each of the participants over the course of a month. All interviews were audio recorded, transcribed verbatim, and translated into English. The initial interview protocol (see Appendix A) focused on participants' experiences with language and their perspectives of IBE. While on site, we decided to adopt a more informal conversational interview approach, allowing for more flexibility and higher cultural sensitivity, understanding that "cross-cultural inquiries add layers of complexity to the already-complex interactions of an interview" (Patton, 2002, p. 391). Depending on the specific context and participant being interviewed, we adapted our interviewing style based on our understanding of the situation. 


\section{Data Analysis}

Once transcribed into Spanish and translated into English, each transcript was analyzed with both emic and etic methods in order to identify key phrases, terms, and practices special to the participants in the study (Patton, 2002). Emic refers to emergent analy tic categories and etic refers to researcher-imposed analytic categories (Reybold \& Halx, 2012). Our etic analysis drew from the research questions to provide structure for comparison across participants' responses. Constant comparative method (Charmaz, 2006) was applied to data analysis in three phases: each transcript was analyzed independently through an open coding process in which "concepts are identified and their properties and dimensions are discovered in the data” (Strauss \& Corbin, 1998, p. 101).

After an initial code list was created through repeated readings of the transcripts, we axial coded all the data. Axial coding involves establishing relationships between the categories and subcategories that emerge from the data (Strauss \& Corbin, 1998). Once this was completed, we generated more abstract categories that unified themes representative across participants. Throughout data analysis we continuously returned to the transcripts to ensure that our interpretation of the overarching themes represented the participants' words and experiences.

\section{Findings and Analysis}

The following section presents the findings from this single-case study that investigated Indigenous teachers' perspectives of language, culture, and IBE. For the interest of space, the findings and discussion will focus on the major themes that emerged when analyzing across the participants. The first major theme focuses on how teachers perceive their agentic role in language revitalization and mother tongue education. This theme serves as a springboard for the second, which explores how agency is expressed through the process of negotiating language and understanding through literacy. Throughout the findings, we draw upon the voices of the participants because the primary focus of this research is their perspectives of IBE. Although the interviews were conducted in Spanish, the participants' second (or third) language, then translated into English, every effort was made to ensure that their words and meanings were captured, while we fully acknowledge that some things will always be lost in translation. The responses of the teachers were collected in written and recorded oral formats, then the translations were reviewed by one researcher fluent in Spanish and English in order to verify consistent translation across all four translators.

\section{The Role of Education in Revitalization}

Many of the participants were raised within an educational/political system, during or shortly after the civil war, that mandated Spanish-only instruction or utilized mother tongue education for the sole purpose of gaining fluency in Spanish. Growing up, they spoke Ixil at home and within the community but were immersed into Spanish upon attending school. María described her early experiences in school: "En la escuela privada, sólo nos hablaban en español porque en esos días, venían de otros lugares o regiones ... pues no podían hablar en ixil. [In the public school they only spoke to us in Spanish because at that time the teachers, they were from other places or regions... so they couldn't speak in Ixil.]" The teachers did not regularly see their language or culture represented in the classrooms. Due to centuries of oppression, genocide, and policies that did not support mother tongue education, the Ixil language and culture became in danger of extinction. 
"If not, it will die." Throughout our conversations, the participants expressed their beliefs about the role of education in language oppression or revitalization. When discussing the role of schools in teaching Ixil, Carlos shared that "Sí, porque es nuestra lengua maternal. Si no, morirá. Es nuestra responsabilidad - la responsabilidad enseñarlos en los dos idiomas. [Yes, because it's our mother tongue. If not, it will die. It is our responsibility - the teachers' responsibility to teach them both languages.]" María recognized the loss of Ixil within the community, saying "es importante enseñar a los niños hablar en ixil porque antes lo estaban perdiendo y ahora no somos muchos que hablamos Ixil [it's important to teach the kids to speak Ixil also because in previous years they were losing it and now there aren't many of us who speak Ixil]." She further reflected on the difficulties that native Ixil speakers face within the context of intergenerational loss of language:

...Creo que hay muchas cosas de que hablamos que tienen nombres en español, pero es difícil para nosotros dar nombres a algunas cosas en ixil porque hace mucho tiempo nuestros abuelos, que ya no están, sabían los nombres para todo, pero nosotros no. Creo que es porque no nos enseñaban en la escuela; no lo recibimos en nuestra educación. (emphasis added). Entonces, había cosas que entendían, pero ahora no podemos llamarlos en ixil.

[I think there are many things that we talk about that have a name in Spanish, but it's difficult for us to name some things in Ixil because a long time ago our grandparents who are no longer here knew the name for everything, but we don't. I think that's because they didn't teach us in school; we didn't get that in our education (emphasis added), so there were things they understood but now we cannot name things in Ixil.]

María laments the current status of the language and the fact that loanwords have already begun to enter the Ixil language.

“This is insurance." While reflecting on the significance of bilingual education for the lives of their students, many teachers discussed the importance of language in teaching and learning, and for communicating within and outside the community. Some shared their beliefs on ways in which Ixil was an important pedagogical vehicle for both teaching and learning. As Jairo explained, "Porque ayuda al profesor enseñarlos por su lengua, por ejemplo, si un niño tiene una duda, puedes explicárselo en ixil. [Because it helps the teacher to teach them through their language, for example, if a kid has a doubt you can explain it to him in Ixil.]" Another participant shared that ". . . hay algunos niños y puede que no entiendan algún tema en español. Entonces si lo explicamos en ixil y lo entiendan rápido en una manera básica. Para mí, ixil es importante también para enseñar, para el currículo, y tal. [ ...there are some kids who might not understand some topic in Spanish, so if we explain it in Ixil, they understand quickly in a basic way. For me, Ixil is important also for teaching, for curriculum, and so on.]” Being able to support children through their mother tongue was an important part of their role as teacher.

Ximena shared her perspectives on ways in which learning both languages serve the children; "La educación bilingüe les ayuda tener comunicación con otras personas. Hay algunos niños que hablan español y otros no. Este seguro que pueden hablar con otras personas. [Bilingual education helps them to be able to have communication with other people. There are some kids who speak Spanish and others who don't. This is insurance 
(emphasis added) that they can talk with other people.]” For María, Spanish also served as the connecting thread for communication across Mayan and Ladino ethnic groups:

...la importancia de hablar otra lengua es que cuando vamos a un lugar, porque en diferentes lugares hablan diferentes lenguas, y la lengua que hablan en la mayoría de lugares es el español, entonces, creo que es importante saber el español también para comunicar con personas afuera del lugar en que estamos.

[...the importance of speaking another language is that when we go someplace, because in different places, they speak different languages, and the language they speak in most places is Spanish, so I believe it's important to know Spanish as well in order to communicate with other people outside the area where we are.]

The early childhood teacher also explained how some parents are now teaching their children Spanish at home, highlighting the significance of knowing both languages for survival and linguistic changes within the community. In her estimulacion temprano classroom and community outreach program, Ximena introduces Spanish words through games and books to children as young as newborns to four year olds.

The urgency for early development of both languages is a value shared by many of the teachers. Carlos discussed how children without opportunities to learn Ixil and Spanish face barriers to accessing jobs as they grow older, saying "Es un requisito para conseguir un trabajo - saber ixil. Si dan un examen, quizás no pueden contestar las preguntas. Por eso es importante saber nuestra lengua materna y otra lengua. [It's a requirement to get a job - to know Ixil. If they take the test, they might not be able to answer the questions that's why it's important to know our mother tongue and another language.]” Bilingualism within the Ixil community enhances opportunities for economic survival and a better quality of life. Spanish, in particular, is the gatekeeper to jobs outside of sustenance farming, the primary source of income for most families in the region. The use of bilingual education insures student ability to learn at a higher level due to their improved use of Mother Tongue Ixil as a building block for second language acquisition of Spanish, along with having improved economic opportunity as they grow older by having Spanish language competence when entering the job market.

\section{Interculturality and Literacy}

Since 2010, the NGO has supported the Ixil Emergent Reading program at the Diego Edwards School; positioning teachers as the language experts to write and illustrate books in Ixil. Throughout this process, teachers expressed their agency through the creation, negotiation, and collaboration of writing books that represent Ixil language and culture. The participants shared their emerging understanding of language, paralleled with concerns and uncertainty about what it means to be bilingual.

"We have created the books." In describing agency as something that people do, not something they have, Priestley, Biesta, and Robinson (2012) stated that "viewing agency in such terms helps us to understand how humans are able to be reflexive and creative, acting counter to societal constraints, but also how individuals are enabled and constrained by their social and material environments" (p. 3). Through this lens, teachers are seen not only as developers of books, but also as agents of change through their actions. María proudly shared that: 
Pues, la diferencia que existe entre esta escuela y la escuela pública es que aquí en nuestro establecimiento tenemos libros en ixil y también nosotros, los profesores, hemos creado los libros especialmente en ixil, mientras que en las otras escuelas públicas, quizás dan un curso en ixil pero los profesores sólo dan palabras o “¿cómo se dice esto en ixil?” y todo eso, pero no pueden compartir libros.

[Well, the difference there is between this school and the public school is that here in our establishment we have books in Ixil and also we teachers have created the books especially in Ixil (emphasis added), whereas in the other public schools they might give a course in Ixil but the teachers just give words or "how do you say this in Ixil?” and all that, but they cannot share books.]

Many of the teachers talked about the process of creating books in their mother tongue and how they constructed meaning through writing, negotiation, and collaboration. As Jairo explained, "Creo que trabaja en nuestro favor que como hacemos los libros y escribimos los borradores de los libros, los profesores aprendemos mientras lo hacemos. [I think it works in our favor that as we're making the books and we write up drafts of the books, the teachers are learning as we do it.]" They explained the sense of agency they felt as well as their appreciation for the reflective process involved in the creation of the books.

"More than anything in the writing." Writing and professional development opportunities were essential components to being bilingual for the teachers and students at the Diego Edwards School. The teachers expressed their views on what it meant to be bilingual and perceived barriers on how to achieve bilingualism. Carlos recognized the importance of literacy in supporting language development, explaining, "También es importante porque los estudiantes escriben, y les apoya. No es sólo hablar. Necesitan aprender escribir ... en la manera correcta. Porque hay algunos que lo hablan, pero no saben escribirlo. [It's also important because they write, and it supports them. It's not just to talk. They need to learn how to write... in the right way. Because there are some who speak it, but they don't know how to write it.]" When discussing ways in which writing supports their own professional development, teachers found it difficult to write in their mother tongue. María shared her concerns about writing in Ixil:

... Puedes confundirte porque una cosa es que algunos dicen que escribes tal y tal palabra en esta manera y otros dicen, no, esta manera es correcta. Entonces, no hay una regla por la manera específica para escribir en ixil o, este, si una palabra se debe escribir junta o separada. Pero en el español entendemos porque hay una gramática, pero en ixil no hay. Entonces, hay personas que quizás saben escribir en ixil, pero no necesariamente saben si palabras deben estar escritas juntas o separadas y es por eso.

[... You can get confused because one thing is that some say you write such and such word in this way and others say, no, this way is correct. So, there isn't any regulation/rule on the specific way to write in Ixil, or like if a word should be written together or separate. But in Spanish we understand because there's a grammar, but in Ixil there's not. So, there are people who might 
know how to write in Ixil, but they wouldn't necessarily know if words should be written together or separated so that's why.]

The principal further went on to explain the professional development needs of the teachers; "Creo que todos los profesores necesitamos - a alguien que nos puede corregir, como debemos hacer cosas y cuál es correcto y cuál no es. Más que todo en escribir. [I believe all the teachers we need - someone who can correct us, how we should do things and which is correct and which isn't. More than anything in the writing (emphasis added)]." She explained that she and many of the other teachers were concerned about "getting it right" and preserving the true language.

Collaborative epistemology. The teachers were constantly negotiating their understanding of language through the process of writing - creating stories, collaborating with each other, and consulting with elders who could "correctly" write in Ixil. When discussing perspectives of this process, one participant explained:

Cuando los profesores escribimos los libros en ixil, hacemos grupos y escribimos lo que nos parece bien, y entonces, entre todos los profesores, hablamos de lo que sería la forma correcta en ixil y todo eso, así que no serán errores en los libros que trabajamos y consultamos con las personas que saben también, y nos ayudan.

[When we teachers write books in Ixil, we form groups and we write what looks good to us, and then, between all the teachers, we talk about what would be the correct Ixil form, and all that so there won't be errors in the books that we work on and we consult with the people who know as well, and they help us.]

The teachers embraced collaboration, not only with each other and the community, but with the professional development volunteers as well. Ximena expressed her interest in learning "una otra manera de hacer actividades con los niños [another way to do activities with the kids]" and Mara shared "el taller nos va a ayudar mucho en el future porque quizás no habíamos sabido eso. [the workshop will help a lot in the future because maybe we might not have known that.]" Carlos described this collaborative epistemology in the following way: "podemos compartir lo que aprendemos y esa es la única manera en que podemos aprender, es así que podemos aprender conocimiento nuevo [we can share what we learn and that's the only way we can learn, that's how we can learn new knowledge.]"

During the professional development workshops, teachers were provided idiomatic biography prompts to think and write about regarding their own experiences with language. María recognized the benefits in this opportunity and developed a more inclusive understanding of how writing supports language, literacy, and professional development. She shared: "Creo que es el más importante para alguien mejorar hablar de escribir [I believe it's the most important for somebody to get better talking about writing]" and that "no importa cuál idioma que sea, o sea en ixil o español. [it doesn't matter which language it's in, be it in Ixil or Spanish." Having the opportunity to sit with her peers outside of the classroom and practice writing personal stories in paragraph form was an innovative development tool; "quizás las se hacen las preguntas y las contestamos pero escribiras en párrafos, para mí, es muy importante [maybe the questions are posed and we answer them but to write them in 
paragraphs, for me it's very important.]" The teachers found this opportunity for collaboration to be affirming as well as helpful.

\section{Discussion}

At the beginning of this research project, we hypothesized that the teachers' attitudes and experiences of language and culture would reflect the current literature focused on IBE in other Latin American countries. This included prioritizing bilingual over intercultural education (Tubino, 2013), emphasizing literacy instruction over cultural identity (Valdiviezo, 2010), and "rather than bilingual education, what has currently been experienced in the socalled bilingual schools is the use of the Mayan languages as a bridge to mastering the Spanish language" (Herrera \& Wedin, 2010, p. 245). What we found, however, was that these initial hypotheses were constrained by our assumptions and preconceptions of what IBE should look like and the capability of teachers to enact interculturality in the classroom. Through engaging in reflexive practice and revisiting the transcripts, we allowed the teachers' narratives to define our understanding and interpretation, thus transforming our conceptualization of IBE and what it means to be an interculturally competent researcher.

When we thought of interculturality in practice, our initial assumption was that the development of intercultural understanding through "the sharing of experiences" between culturally different groups was the central focus and took place within the same physical space. In Guatemala, the majority of Mayan communities remain isolated from each other and from the dominant Ladino population, making access to cross-cultural interactions difficult; hence, our initial preconceptions. However, Medina-Lopez-Portillo and Sinnigen's (2009) idea that interculturality can be enacted within imaginary spaces broadened our narrow understanding and opened our eyes to the teachers' lived realities. Through understanding Indigenous teachers' perspectives of language, culture, and interculturality are critical to add to the discussion on how these teachers choose mother tongue language revitalization over numerous cultural, economic, and political pressures.

The data revealed that teachers conceptualized notions of interculturality and IBE by expressing their agency through the creation of books that represented Ixil language and culture. The burden of revitalizing Ixil language and culture through the development of an Ixil writing system and subsequent print materials has been placed on the shoulders of local teachers and NGOs. During the collaborative process the teachers are negotiating their understanding of language, the role of education in supporting their mother tongue, and what it means to be bilingual.

\section{Implications for Future Research}

These findings have important implications for the field of international education, specifically relating to teacher professional development, social justice education, bilingual literacy instruction, and for broader audiences such as educational policy makers, international development institutions, and Indigenous-led social movements. Furthermore, those working in the fields of language revitalization and mother tongue education may consider ways to emphasize the importance of collaboration and agentive roles of teachers. As discussed by Fishman (1991), language revitalization should grow out of an internal response from the community and involve individuals, systems, and any potential stakeholders.

This study also highlights the notion that reflective practice is essential in all research. Particularly in dealing with Indigenous communities with ways of knowing that are distinct from traditionally "Western" dominant values as represented by formal 
education, it is important for researchers, practitioners, and policy members to be aware of their own cultural norms, values, and perspectives. This includes how we define culture and interculturality.

\section{Conclusion}

Interculturality as part of IBE support equitable access to developing new social configurations that lead to effective and equitable intercultural exchange. Within the last decade, new social configurations supporting mother tongue-based bi/multilingual education and access to quality education for Mayan groups have been supported in educational policy. However, there are limited governmental resources in place supporting implementation of these policies; "by establishing IBE the states appear to have done what was politically correct before really committing to this goal and process" (Internacional de la Educación, 2011, p. 21). In the rural, Indigenous community of Santa Avelina, it is within the collaborations of local teachers, the NGO, and volunteers that IBE is supported. This single-case study analyzed themes across four information-rich cases to gain a better understanding of teachers' perspectives of language, culture, and interculturality.

Our findings suggest that teachers were critically aware of their role in language revitalization and shared complex understandings of bilingualism. Teachers expressed their agentive role and support of IBE through the collaborative process of creating books representing Ixil language and culture. The intergenerational loss of language was evident, as teachers frequently voiced confusion on how to write 'correctly'. Teachers have to rely on NGO volunteers to provide professional development opportunities, which presents significant implications for future research that examines cross-cultural collaborations, intercultural competence, and IBE within the context of post-conflict Guatemala. Furthermore, it is possible to scale up the process used in Santa Avelina, most easily with other schools containing Ixil-speaking populations, by beginning the publication process with Santa Avelina teacher produced books and then working to produce more within other schools. However, this process is time-consuming and expensive and is therefore, it is not likely to be undertaken on its own without heavy support from outside non-profit groups. The larger barrier to expanding Santa Avelina's model in the region is lack of government funding, in addition to the fact that the books produced are not traditional reading instruction books.

\section{References}

Alidou, H., Glanz, C., \& Nikiema, N. (2011). Quality multilingual and multicultural education for lifelong learning. International Review of Education, 57, 529-539. doi: $10.1007 / \mathrm{s} 11159-011-9259-\mathrm{Z}$

Arias, A. (2006). The Maya movement, postcolonialism and cultural agency. Journal of Latin American Cultural Studies, 15(2), 251-262. doi:10.1080/13569320600782310

Bennett, J. M., \& Bennett, M. J. (2004). Developing intercultural sensitivity: An integrative approach to global and domestic diversity. In D. Landis, J. M. Bennett, \& M. J. Bennett (Eds.), Handbook of intercultural training (3rd ed., pp. 147-165). Thousand Oaks, CA: SAGE Publications.

Berger, P., \& Luckmann, T. (1966). The social construction of reality. Garden City, NY: Doubleday.

Bitar, M., Pimentel, C., \& Juarez, A. (2008). Language gain, language loss: The production of K'iche'tellano in highland Guatemala. International Journal of Language Society and Culture, (26), 25-33. 
Blight, M. (2012). Cultures education in the primary years: Promoting active global citizenship in a changing world. Journal of Student Engagement: Educational Matters, 2(1), 49-53.

Central Intelligence Agency. (2014). The world factbook: Guatemala. Retrieved May 10, 2014, from https://www.cia.gov/library/publications/the-worldfactbook/geos/gt.html

Charmaz, K. (2006). Constructing grounded theory: A practical guide through qualitative analysis. Thousand Oaks, CA: SAGE Publications.

Creswell, J. W. (2007). Qualitative inquiry and research design: Choosing among five traditions (2nd ed.). Thousand Oaks, CA: SAGE Publications.

Douglass, B. J. \& Moustakas, C. (1985). Heuristic inquiry: The internal search to know. J. Humanistic Psychology, 25, 39-55.

Fishman, J. A. (1991). Reversing language shift: Theoretical and empirical foundations of assistance to threatened languages. Clevendon, U.K.: Public Matters.

Guatemala Human Rights Commission. (2011). Genocide in the Ixil Triangle. Retrieved May 10, 2014, from http://www.ghrc-usa.org/resources/important-cases/genocidecases/genocide-in-the-ixil-triangle/

Hamilton, M. F., Richardson, B. J., \& Shuford, B. (1998). Promoting multicultural education: A holistic approach. College Student Affairs Journal, 18(1), 5-17.

Helmberger, J. L. (2006). Language and Ethnicity: Multiple Literacies in Context, Language Education in Guatemala. Bilingual Research Journal, 30(1), 65-86. doi:10.1080/15235882.2006.10162866

Herdoiza-Estevez, M., \& Lenk, S. (2010). Intercultural dialogue: Discourse and realities of Indigenous and mestizos in Ecuador and Guatemala. Interamerican Journal of Education for Democracy, 3(2), 196-223.

Herrera, L. M., \& Wedin, A. (2010). Bilingualism and bilingual education in a complex context. Language, Culture and Curriculum, 23(3), 235-249.

Hornberger, N. (1998). Language policy, language education, language rights: Indigenous, immigrant, and international perspectives. Language in Society, 27(4), 439-458.

Internacional de la Educación. (2011). Intercultural multilingual education in Latin America: Mexico, Guatemala, Colombia, Brazil, Ecuador, Peru, Bolivia and Paraguay, and Norway (pp. 1-50). Costa Rica: Education Internacional Latin America Regional Office.

Retrieved from http://www.ei-ieal.org/index.php?option $=$ com_content\&view $=$ section\&layout $=$ blog\&id $=13 \&$ Itemid $=40$

Lewis, P. M., Simons, G. F., \& Fennig, C. D. (Eds.). (2014). Ethnologue: Languages of the world (17th ed.). Dallas, TX: SIL International. Retrieved from http://www.ethnologue.com/language/ixl

Marques, J. \& Bannon, I. (2003). Central America: Education reform in a post conflict setting, opportunities, and challenges. World Bank CPR Working Papers: paper number 4.

Maxwell, J. A. (2013). Qualitative research design: An interactive approach (3rd ed.). Los Angeles: SAGE Publications. Retrieved from http://www.sagepub.com/textbooks/Book234502?prodId=Book234502

McCarty, T. L. (2003). Revitalising indigenous languages in homogenizing times. Comparative Education, 39(2), 147-163. http://dx.doi.org/10.1080/03050060302556

Medina-Lopez-Portillo, A., \& Sinnigen, J. H. (2009). Interculturality versus intercultural competencies in Latin America. In D. K. Deardorff (Ed.), The SAGE handbook of intercultural competence (pp. 249-263). Thousand Oaks, CA: SAGE Publications. 
Instituto Nacional de Estadística Guatemala. (2010). Poblacíon Nacional de Guatemala. Guatemala City, Guatemala.

Patton, M. Q. (2002). Qualitative research \& evaluation methods (3rd ed.). Thousand Oaks, CA: SAGE Publications.

Paulston, C. B. (1997). Language policies and language rights. Annual Review of Anthropology, 26, 73-85.

Priestley, M., Biesta, G., \& Robinson, S. (2012). Understanding teacher agency: The importance of relationships. Presented at the American Educational Research Association, Vancouver. Retrieved from http://www.academia.edu/1473772/Understanding_teacher_agency_The_importa nce_of_relationships

Reybold, L. E., \& Halx, M. D. (2012). Coming to terms with the meaning of interdisciplinary: Faculty rewards and the authority of the discipline. The Journal of General Education, 61(4), 323-351.

Reybold, L. E., Lammert, J. D., \& Stribling, S. M. (2013). Participant selection as a conscious research method: Thinking forward and the deliberation of 'Emergent' findings. Qualitative Research, 13(6), 699-716. https://doi.org/10.1177/1468794112465634

Richards, J. B., \& Richards, M. (1997). Mayan language literacy in Guatemala: A sociohistorical overview. In N. H. Hornberger (Ed.), Indigenous literacies in the Americas: Language planning from the bottom up (pp. 189-211). Berlin: Mouton de Gruyter.

Rogers, E., Hart, W., \& Miike, Y. (2002). Edward T. Hall and The History of Intercultural Communication: The United States and Japan. Keio Communication Review. 24.

Skutnabb-Kangas, T. (2000). Linguistic genocide in education - or worldwide diversity and human rights? Mahwah, NJ: Erlbaum.

Spitzberg, B. H., \& Changnon, G. (2009). Conceptualizing intercultural competence. In D. K. Deardorff (Ed.), The SAGE handbook of intercultural competence (pp. 1-52). Thousand Oaks, CA: SAGE Publications.

Strauss, A., \& Corbin, J. (1998). Basics of qualitative research (2nd ed.). Thousand Oaks, CA: SAGE Publications.

Tangen, D., Mercer, K. L., Spooner-Lane, R., \& Hepple, E. (2011). Exploring intercultural competence: A service-learning approach. Australian Journal of Teacher Education, 36(11), 62-72.

Tubino, F. (2013). Intercultural practices in Latin American nation states. Journal of Intercultural Studies, 34(5), 604-619. doi:10.1080/07256868.2013.807538

UNESCO. (2003). Education in a multilingual world (UNESCO position paper). Paris: UNESCO.

United Nations International Children's Emergency Fund. (2019). Guatemala Profile (UNICEF Database). Paris: UNICEF.

United States Institute of Peace. (1997). Truth commission: Guatemala. Retrieved May 10, 2014, from http://www.usip.org/publications/truth-commission-guatemala

Valdiviezo, L. A. (2010). Indigenous worldviews in intercultural education: Teachers' construction of interculturalism in a bilingual Quechua-Spanish program. Intercultural Education, 21(1), 27-39.

Veilleux, I. \& Bournot-Trites, M. (2005). Standards for language competence of French immersion teachers: Is there a danger of erosion? Canadian Journal of Education, 28(3), 487-507. http://dx.doi.org/10.2307/4126480 
Yazzie-Mintz, T. (2011). Native teachers' beliefs and practices: Choosing language and cultural revitalization over uniformity and standardization. Contemporary Issues in Early Childhood, 12(4), 315-326. https://doi.org/10.2304/ciec.2011.12.4.315

Yin, R. K. (1994). Case study research: Design and methods. Thousand Oaks, CA: SAGE Publications.

\section{About the Authors}

Kelly Dalton is the Director of the Saints' Center for Service at Marymount University in Arlington, VA. She holds a B.S. in Human Nutrition, Foods and Exercise, an M.S. in Nutrition Education and Behavior from Virginia Tech, along with a Registered Dietitian license, and a Ph.D. in International Education from George Mason University. Her research explores intercultural education, community engaged learning, and social justice. She previously led university programs and taught courses in nonprofit management, service learning, and integrative studies. Her research and work has spanned across locations in the U.S., Pakistan, and Guatemala.

Sarah Hinshaw is an international early literacy consultant and year 1 teacher at Onehunga Primary School in Auckland, New Zealand. She holds a B.A. in Sociology and Biology, an M.Ed. in Curriculum and Instruction, along with certifications in nonviolence training, education diplomacy, and library science. Her research explores literacy, peace education, $21^{\text {st }}$ century skills building, and community literacy advocacy. She works primarily with low income schools, new immigrant populations, and second language learners. Her research and work have taken her to schools across the U.S., Guatemala, South Africa, and Guatemala.

John Knipe is an Assistant Professor of English and Spanish and the International Student Liaison at Limestone College in Gaffney, SC. He holds a B.A. in Spanish, an M.Ed. in Integrated Curriculum and Instruction, an M.A. in Spanish Linguistics, and a Ph.D. in International Education and Linguistics. His research explores the links between language, power, and education. He has worked with a number of endangered languages (e.g., Scottish Gaelic, Ixil) minority languages (e.g., Scots, Spanish in the U.S.), and nonstandard languages (e.g., African American Vernacular English, Spanglish). He has also conducted research with regard to acculturative stress and second language acquisition experiences of international students studying in the U.S. 


\section{Appendix A: Interview Protocol}

¿Cómo se identifique culturalmente?

How do you identify yourself culturally?

Trasfondo lingüistica.

Language background.

1. ¿Cómo los aprendió?

How did you learn each one?

2. ¿Con quiénes habla cada lengua?

With whom do you speak them?

3. ¿En cuáles puede leer y escribir?

In which are you able to read and write?

4. ¿Qué bien?

How well?

Trasfondo educativa.

Educational Background.

5. ¿Qué tipo de entrenamiento recibió para ser profesor(a)? ¿Cuáles clases pertinentes ha tomado?

What type of training did you receive to become a teacher? What relevant classes have you taken?

6. ¿Qué tipo de entrenamiento actual recibe para ayudar con su enseñanza? What type of current training do you receive to aid with your teaching?

Reflección.

Reflection.

7. ¿Por qué ha escogido enseñar en la Escuela de Diego Edwards?

Why have you chosen to teach at Diego Edwards School?

8. En su opinión, ¿por qué es necesario que sus estudiantes reciben instrucción en Ixil? In your opinion, why is it necessary that students receive instruction in Ixil?

9. ¿Qué papel tiene Ud. en el desarrollo lingüístico de sus estudiantes? Su desarrollo cultural? Su desarrollo cognitivo?

What role do you play in the linguistic development of your students? Their cultural development? Their cognitive development?

10. ¿Cree Ud. que es importante que los estudiantes aprenden leer en Ixil y español? Explique. 
Do you believe it is important that students learn to read in both Ixil and Spanish? Explain.

11. Cree Ud. que aprenderían tanto si se les enseñaba solo en español? Explique.

Do you believe they would learn as much if they were taught solely through Spanish? Explain.

12. ¿Cuáles son los beneficios de un sistema educativo bilingüe? ¿Un sistema monolingüe?

What do you think are the benefits of a bilingual educational system? A monolingual system?

13. ¿Cuáles cosas quisiera ver en la escuela que no ya no existen?

What things would you like to see in the school that do not currently exist?

14. ¿Cuáles conecciones, si cree que existen, vee Ud. entre el uso de Ixil en la clase y los derechos humanos?

What connections, if any, do you see between human rights and the use of Ixil in the classroom?

15. ¿Qué papel tiene Ud. como agente de justicia social en la clase? Explique.

What role do you play as an agent of social justice in the classroom? Explain.

16. ¿Qué más quiere Ud. que nosotros sepamos de sus experiencias en la Escuela de Diego Edwards?

What else would you like us to know about your experiences at Diego Edwards School? 